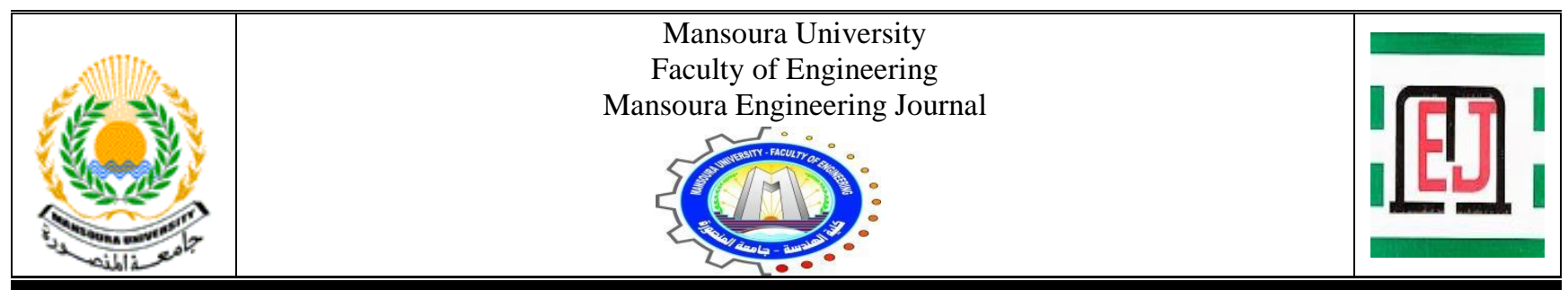

\title{
Upgrading urban spaces in slums as a tool to achieve Social Sustainability (Making slums livable) - The case study of Meit-Elwan slum - Kafr El Sheikh city- Egypt
}

\author{
Rania Abd AL Lateef Ghanam* and Ahmed Salah El-Deep
}

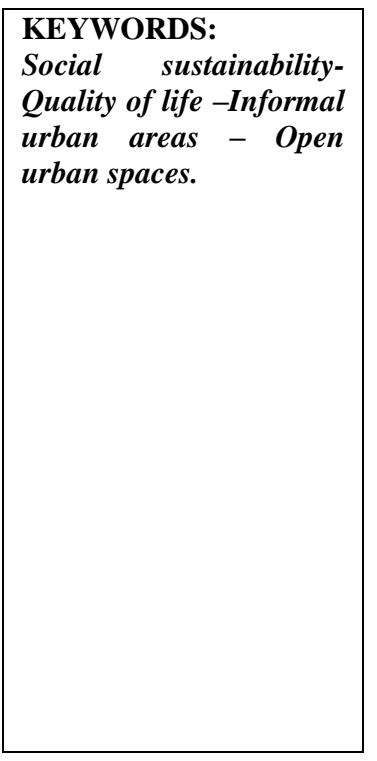

Abstract-One-third of the population of the developing countries lives today in slums, Urbanization of the planet stands at about $50 \%$ of the population, so rapid urbanization, mainly by the poor, and the increasing of slums to accommodate the population growth, so cities will be designed by the poor, there is a great need to achieve social sustainable development in slums to save resources and to improve the slum's dwellers quality of life.

The research aims to reach a mechanism that combines the elements of sustainable urban development in urban communities based on achieving the humanitarian needs of the population, providing a model for achieving social sustainability in the urban environment of slums

The research follows the theoretical approach in studying concepts related to social sustainability and its dimensions, then following the analytical approach as it discusses the social sustainability development design principles and analysis case studies for sustainable upgrading of slums in India and Columbia to provide indicators of achieving social sustainability development for slums, then the paper provides an applied study to achieve these indicators in the slum of Meit Elwan in Kafr Alsheikh city in Egypt to turn it into a more livable slum, The research vision of the slum upgrading process follows street-led city wide slum upgrading approach which was developed by UN-Habitat (2012-2017).

Received: (08 January, 2021) - Revised: (01 May, 2021) - Accepted: (27 May, 2021)

*Corresponding Author: Rania Abd AL Lateef Ghanam: is with the Department of Architecture, Faculty of Engineering and Information Technology, Onaiza Collages, K.S.A - is with also the Architecture Department, Faculty of Engineering, Kafr AL sheikh University, Egypt (Email: raniaghanam77@gmail.com)

Ahmed Salah El-Deep, is with the Architecture Department, Faculty of Engineering, Kafr Alsheikh University, Egypt (E-mail: ahmed_aboelnaser@eng.kfs.edu.eg)

\section{INTRODUCTION}

$\mathrm{U}$ RBANIZATION is considered an organized process that combines the built environment with the human being. This process includes overlapping and exchanging roles between urbanism and human needs.

The urban development of the existing communities is making harmony between the urban environment with its physical and human components, as it mainly aims at upgrading the urban identity based on the culture of the population in the city. The overlap between the planning and design of urban communities based on the achievement and provision of human needs can be expressed in what is called social sustainability. This concept helps to change, improve 
and draw the relationship between people through changing the behavior of the population and users by using the laws and legislations; which in turn works to provide a degree of interaction between the population and each other and between them and the surrounding urban environment (Elmorshidy, Kamel, 2015)

\subsection{Research Problem}

The process of planning and designing urban communities is one of the ways to achieve the quality of urban life. This process should highlight the importance of the social aspect and its effects on the continuity and success of urban development.

Therefore, the research problem is represented in the lack of balance and interaction between the environmental, economic, administrative, executive and urban aspects in the absence of the concept of social sustainability as one of the most important elements in achieving the quality of urban life when designing human urban communities.

\subsection{Objectives}

This research aims to: -

1- The research aims to reach a mechanism that combines the elements of sustainable urban development in urban communities based on achieving the humanitarian needs of the population

2- Providing a model for measuring social sustainability in the urban environment of informal areas, where the social factor is the most influencing the urban development situation.

\subsection{Methodology}

The research follows the theoretical approach in studying concepts related to social sustainability and its dimensions, then following the analytical approach in studying the selected case studies to extract the points of measuring social sustainability in informal urban communities.

And the research goes by using the applied approach by selecting an informal area to apply and measure the possibility of achieving social sustainability to ensure the quality of urban life in this area

\section{SLUMS OR INFORMAL HOUSING?}

A slum is a word often used to describe informal settlements that have inadequate housing and squalid, miserable living conditions and overcrowded, they also called hidden housing, random housing, poor and illegal neighborhoods (www.citiesalliance.org)

They lack basic municipal services such as water, sanitation, waste collection, and street lighting, most slums do not have easy access to schools, hospitals, or public places for the community to gather. Many of them have not been serviced and recognized for long periods, in slums, many social indicators are on a downward slide as crime and unemployment are on the rise(www.iiste.org).

some slums provide better living conditions than others, slum dwellers are a diverse group of people with different interests, and backgrounds, Slums are also a significant economic force. In many cities, as much as 60 percent of employment is in the informal sector of the urban population, more than one billion people in the world live in slums, and the developing world, every three people living in cities there is one of them lives in a slum (UN-HABITAT report.2017). Slums also include the need for effective urban open spaces to advance human behavior and achieve social interaction (Taha,2010), most of the open spaces receive sufficient attention, this has led to the creation of a residential environment that does not meet the needs and desires of the population, and harms society's relations in human and social terms (Kasab, Elhosiny,2013).

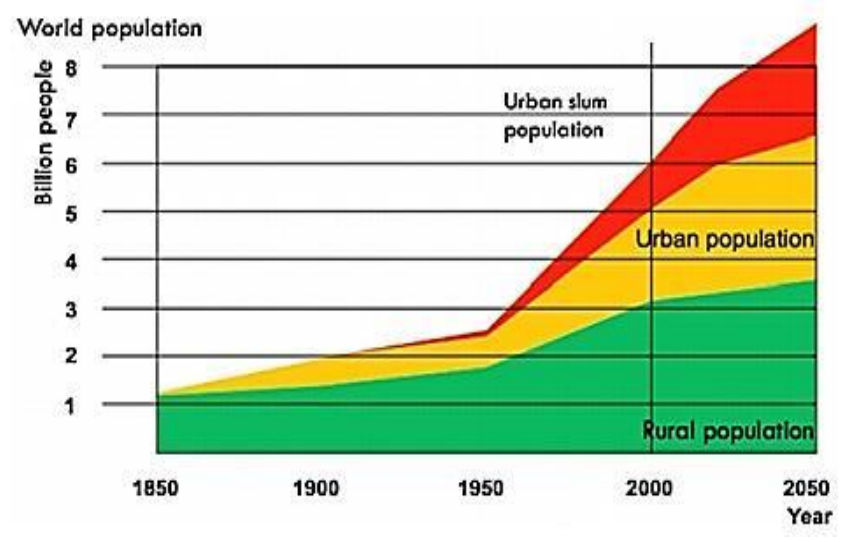

Figure 1: the increase in population in slums over time (Source: sustainable upgrading for informal areas, Saad Ola,others,2019

\section{SUSTAINABILITY CONCEPT}

\subsection{Quality of life}

Quality of life has different meanings, as The product of the interaction between the social, economic and environmental situation that affects humans, (Ontario social development council), It is a general popular expression that means a sense of general well-being felt by the people supported by the surrounding environment in society and considered to be a product of society as a whole (Yousif,2010), it is considered one of the approaches that consider things comprehensively because its goal is to collect a set of factors that reflect : the social, psychological, economic, urban, cultural, and health status of the local population (Theofilou 2013) (fig.2), the quality of life methodologies is considered to be of increasing global concern

\subsection{The social sustainable development}

The concept of sustainable development was defined by the International Commission for Environment and Development in 1987, As an effective use of natural, human, and technology resources to address society's needs without compromising the ability of future generations to meet their requirements, so sustainable development improves the quality of human life socially, economically, and environmentally.

Social sustainability results from the design of the urban environment, how people and spaces relate, and its impact on social relationships. This is improved through development that provides the infrastructure to support a strong community, 
cultural life, opportunities for social communication (El Morshedyu, 2015)

social sustainability development meets social needs and assures that social communication is achieved without prejudice to the standards of privacy by the requirements of urban communities and the types of activities that are intended to provide them with the urban, cultural, and urban focus; which includes ensuring the efficiency of the gathering and increasing the imposition of the urban environment to provide human requirements, desires, and achieving community sustainability and attracting population and its stability through the successive generations, Defining social sustainability with these images leads to the need to refer to human requirements, with a focus on the needs that can be achieved through the design of the urban community

\subsection{The Theories of Human Needs}

The architectural designer aims to meet the living, psychological and spiritual needs of people and relies on his design to study the needs of the different society to make the design successful and appropriate to human behaviors, the study of requirements is a pillar that achieves social sustainability in urban communities, Physiological needsSafety and security needs, Social needs, The need for appreciation and respect and The need for self-realization

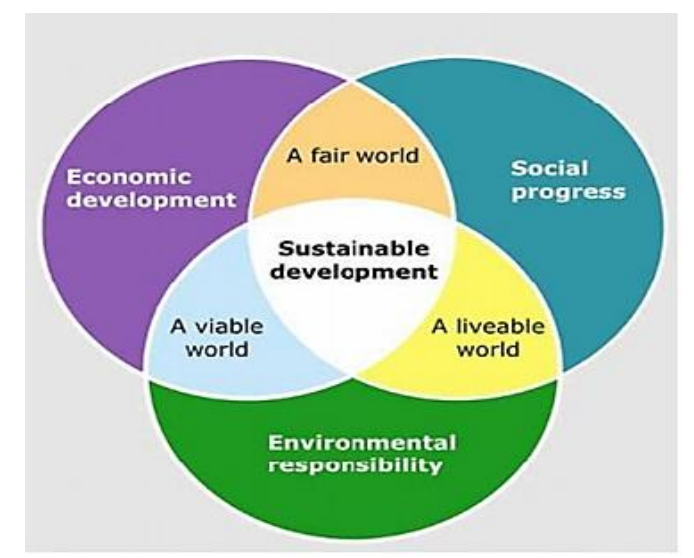

Figure 2: the dimensions of sustainable development , Source: (Theofilou 2013)

\section{3-4 Analysis of the interaction between human needs and urban environment}

TABLE 1:

ANALYSIS OF THE INTERACTION BETWEEN HUMAN NEEDS AND URBAN ENVIRONMENT (SOURCE: THE RESEARCHER)

\begin{tabular}{|c|c|c|c|c|}
\hline \multirow{2}{*}{ 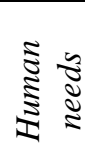 } & \multirow{2}{*}{\multicolumn{2}{|c|}{ Goals }} & \multicolumn{2}{|c|}{ Achievement field } \\
\hline & & & Urban & Architectural \\
\hline \multirow{7}{*}{ 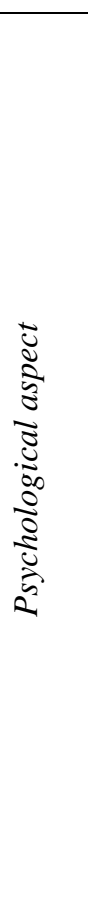 } & \multirow{3}{*}{\multicolumn{2}{|c|}{$\begin{array}{l}\text { Providing comfortable } \\
\text { housing }\end{array}$}} & & $\begin{array}{l}\text {-Housing characteristics: space, } \\
\text { separate space for each use, } \\
\text { saving Current \&future } \\
\text { requirements. }\end{array}$ \\
\hline & & & & $\begin{array}{l}\text {-Thermal comfort: unit } \\
\text { orientation, temperature \&air } \\
\text { paths, distribution of uses } \\
\text { according to the preferred wind. }\end{array}$ \\
\hline & & & & $\begin{array}{l}\text {-Hearing comfort: noise arising } \\
\text { from external voids }\end{array}$ \\
\hline & & & $\begin{array}{l}\text { - Road and street network features, } \\
\text { Separate bike lanes. }\end{array}$ & $\begin{array}{c}\text {-Residential use, Visual and } \\
\text { hearing privacy }\end{array}$ \\
\hline & \multirow{3}{*}{ 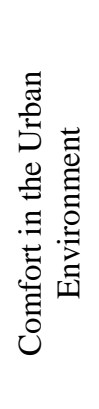 } & $\begin{array}{l}\text { living (healthy and } \\
\text { comfortable } \\
\text { environment }\end{array}$ & $\begin{array}{l}\text {-Characteristics of facilities and services } \\
\text { distribution }\end{array}$ & \\
\hline & & $\begin{array}{l}\text { Affection and } \\
\text { intimacy of places }\end{array}$ & $\begin{array}{l}\text { Characteristics of pedestrian and } \\
\text { forestation passages. } \\
-\quad \text { The level of clarity of urban } \\
\text { environment. }\end{array}$ & \\
\hline & & $\begin{array}{l}\text { Creativity, artistic } \\
\text { expression }\end{array}$ & & $\begin{array}{l}\text { Design of } \text { building facades, } \\
\text { architectural vocabulary and } \\
\text { motifs. }\end{array}$ \\
\hline 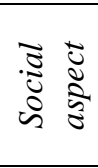 & \multicolumn{2}{|c|}{ Spatial distinction } & $\begin{array}{l}\text { Characteristics of the scheme: consider } \\
\text { of the } \\
\text { Nature ground, permits, site coordination } \\
\text { elements. }\end{array}$ & $\begin{array}{l}\text { Building elevations: The interface } \\
\text { between the facades, distance } \\
\text { between doors and verandas. }\end{array}$ \\
\hline
\end{tabular}




\begin{tabular}{|c|c|c|c|}
\hline \multicolumn{4}{|c|}{ Table 1 (continued) } \\
\hline \multirow{2}{*}{ 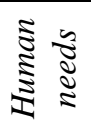 } & \multirow{2}{*}{ Goals } & \multicolumn{2}{|c|}{ Achievement field } \\
\hline & & Urban & Architectural \\
\hline \multirow{5}{*}{ 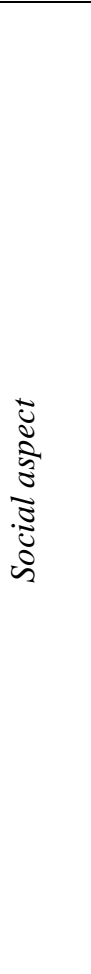 } & $\begin{array}{l}\text { Self-realization, sense of } \\
\text { accomplishment and self- } \\
\text { reliance }\end{array}$ & $\begin{array}{l}\text { A good built environment that achieves } \\
\text { different ownership degrees. }\end{array}$ & $\begin{array}{l}\text { Access to housing: obtaining } \\
\text { housing that meets the } \\
\text { requirements. }\end{array}$ \\
\hline & $\begin{array}{l}\text { Participation in society and } \\
\text { public life }\end{array}$ & $\begin{array}{l}\text { Community services,: } \\
\text { participation in urban spaces }\end{array}$ & \\
\hline & $\begin{array}{l}\text { Affiliation, developing } \\
\text { personal relationships and } \\
\text { close friendship }\end{array}$ & $\begin{array}{l}\text { Characteristics of road network and } \\
\text { relationship to buildings. } \\
\text { Characteristics of urban spaces } \\
\text {-General and Recreational Spaces, Form } \\
\text { and Size of Spaces, Traffic Intensity in } \\
\text { Corridors. } \\
\text {-Recreational spaces of a building or a } \\
\text { group of buildings }\end{array}$ & \\
\hline & Safety and security & $\begin{array}{l}\text {-Street network: lighting elements, } \\
\text { crossing places, -protection from } \\
\text { strangers: street network hierarchy } \\
\text {-Land use characteristics, densities. } \\
\text {-Elevations: The vision, places to sit } \\
\text { outside the residence. }\end{array}$ & $\begin{array}{l}\text { Characteristics of urban spaces: } \\
\text { with a clear composition, and } \\
\text { night lighting. }\end{array}$ \\
\hline & $\begin{array}{l}\text { Feeling fair among } \\
\text { community members }\end{array}$ & $\begin{array}{l}\text {-The ability to obtain a suitable house: } \\
\text { justice in distributing services, various } \\
\text { forms ,easy access, type \& nature }\end{array}$ & $\begin{array}{l}\text {-Housing characteristics: } \\
\text { Efficiency in the form and } \\
\text { function appearance at the housing } \\
\text { level. }\end{array}$ \\
\hline
\end{tabular}

\section{IMPACT OF SUSTAINABILITY CONCEPTS ON ACTIVITIES WITHIN THE URBAN SPACE}

The concept of sustainability is changing by changing the level of engagement, as sustainability at the regional level is to achieve a balance between social, economic, and environmental sustainability, While at the city level, the sustainability of cities is measured by the extent of their flexibility in meeting changing requirements and the ability of its elements and activities to cope with the various changes of society throughout the ages( Wikstorm,2013), As for the detailed levels, sustainability is measured by the size of energy rationalization and resource conservation. As for the sustainability of urban space have been addressed in terms of the sustainability of site coordination in terms of diversity and flexibility (El Eisawy, 2020)

\subsection{Human activity in urban space as a supportive component of life}

\subsubsection{The importance of urban space}

Its importance appears in developing and organizing the relationship of people with space and surroundings so that thay affects each other, Providing comfort for space users, meeting their needs and connecting them to their communities through design, Motivating users to practice various life habits such as eating outdoors, The physical environment in the same space influences people's behaviors because human behaviors are connected and are an integral part of social, cultural, and sensory content. Connecting space with society so that it is difficult to find space without social content (EL Kattan, 2009)

\subsubsection{The human activity in space}

The activity is divided into three main types:

冈 Necessary activities: they depend on meeting the necessary needs only, such as: Going to school, working, the nature of their occurrence affects the perceptible urban environment, they take place during time periods, and are often independent of external conditions, and none of the participants is free to choose (Abdelhalim, 2013).

冈 Optional activities: they subject to the wishes of the users according to the availability of the appropriate conditions as enjoying the natural scenery or enjoying the sun (Kbisch and others, 2015). They take place when the place and the weather conditions call for enjoyment; these activities improve the lives of the people (Abdelhalim, 2013).

囚 Social activities: they depend on the presence of people in public places, such as greeting and chatting, and social activity appears automatically as a direct sequence of the movement of individuals and their presence in the same space (1llia and others, 2019). When the external conditions are appropriate, the optional activities appear to a large degree, and the quality of social activities increases (Abdelhalim, 2013). 


\subsection{Urban spaces as a model of social sustainability} (The criteria of successful urban spaces)

$\checkmark$ Familiarity: - Familiar spaces usually contain shapes and open spaces, buildings and features in their designs familiar and gradual to the elderly in particular, and people in general (Hassan,2014)

$\checkmark$ Legibility: -Assisting people in understanding the space, realizing its components, and the ease of identifying intersections with it and seeing the guiding signs and signs without confusion (Hassan,2014).

$\checkmark$ Distinctiveness: -The ability to give the urban space a clear picture that enables people to visit it and pass it in succession without losing the roads, and distinct streets that reflect the local character of the area and have a group of diverse uses in a compact way(sholihah,2016)

$\checkmark$ Accessibility: - The ability to reach any of the areas and parts of the urban space and to use the places that people need and want to visit and tour, away from any physical, sensory or mental disability, and the ease of dealing with local services and facilities, sidewalks and pedestrian crossings (Makhett,2008)

$\checkmark$ Comfort: - The ability to move between street areas easily and comfortably and providing furnishing elements (Makhett,2008)

$\checkmark$ Safety: - The ability to move in the urban space without fear or anxiety from faltering or falling, and safety from any behavioral deviations from others as a result of imbalance in traditions or weakening in social control means(Hassan, 2014).

\subsection{Urban spaces as a model of social sustainability}

\section{4-3-1 Applying the standards on the streets as one of the} urban spaces

According to the program of sustainable development research unit in the Oxford Institute (OISD), design features for streets that guarantee their continuity and sustainability within the city can be summarized in the following points

- making the small blocks of buildings on a clear network at intersections in general to make it easier to identify these intersections and the surrounding streets

- $\quad$ streets hierarchy from main to sub-branch(Ibrahim,2016)

- Studying winding streets to ensure homogeneity within the urban fabric, and to facilitate the movement of users.

- Taking into account the homogeneity of the specific blocks of street space and the diversity in the urban and urban formation of the street as an effective component of urbanism as a whole (Ibrahim,2016), Diversity of uses including services, facilities and open spaces.

- coordinating the confined area between the pedestrian path and the road and separating them by coordination elements

- The clarity of the buildings entrances directly overlooking the street, Street signs must be shown (landmarks), the buildings are important as well as the distinctive activity areas, Significant intersections are identified.

- Designing and executing the sidewalks, with sufficient width and smoothness, within easy movement and non- slip, Crossings at intersections must be equipped with clearly visible signals for users in general.

- Emphasis on clarifying any differences in the level of movement between the elements of the street (between the sidewalks and automated traffic roads, providing the street with the necessary signs and signs clearly needed choosing suitable wooden seating seats with armrests and backrest side (Ibrahim, 2016) Passenger bus stops are closed with seats, and ground floors are provided with toilet facilities.

4.4 street-led citywide slum upgrading approach developed by UN-Habitat

UN-Habitat has developed Street-led citywide slum upgrading training as trilogy (2012-2017), this approach connects and reconnects slums with the rest of the city by opening up space for infrastructure provision and income generation, enhanced security of land tenure, and set the basis for sustained citywide transformation and local economic development, this approach based on the following axes (Streets as Tools for Urban Transformation in Slums,UNHabitat,2017)

1-integration of slums into the city administration system

2. Implementation in phases

3. Urban mobility and connectivity

4. Fostering economic growth

5. Creation of citizenship

6. Development through strategic participation and partnerships

7. Optimization of density and promotion of mixed uses

8. Enable urban layouts through land readjustment

9. Laying the basis for the provision of security of tenure

10. Supporting safer cities

11. Providing alternatives to 'forced' relocation

12. Planning for disaster risk reduction

13. Ensure a steady flow of funds from a variety of resources

14- Social diversity and mixed activities

\section{V.EXAMPLES OF URBAN SPACES AS A MODEL OF SOCIAL SUSTAINABILITY IN SLUMS}

\section{5-1 Integrated Program in Medellin, Columbia}

In 2005 more than $60 \%$ of the city population of $1,324,804$ lived in informal settlements. It has violent crimes and employment potential in the region (Betancur, 2007).

\section{5-1-1 Methodology of upgrading in Medellin}

The strategy was based on the Integrated Urban Project approach that had public space and mobility, collective urban services, housing consolidation and environment (Betancur,2007), The innovative public transport system based on cable cars (metro cable) linked these areas to the metro and municipal public transport systems which connected the settlements with the rest of the city, improved accessibility and mobility significantly, and created areas of regeneration with an increasing mix of commercial activities, housing improvement, and good public services (Imparato, Ruster,2003). 


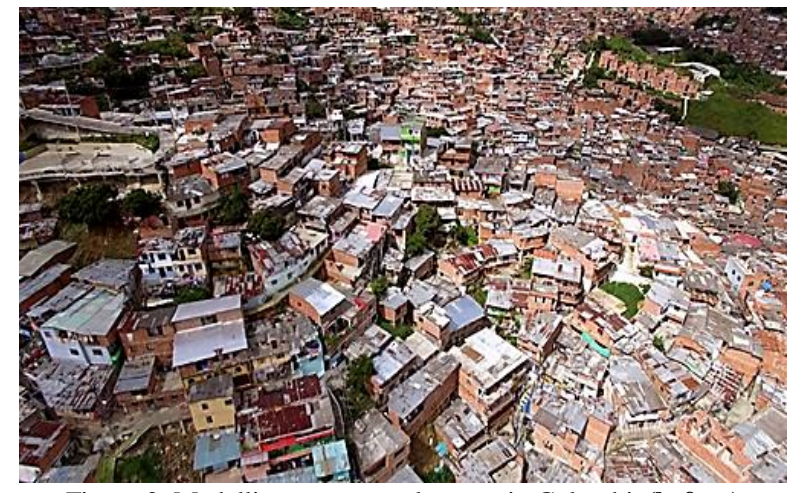

Figure 3: Medellin squatter settlements in Columbia(before) (Source: https://www.shutterstock.com/

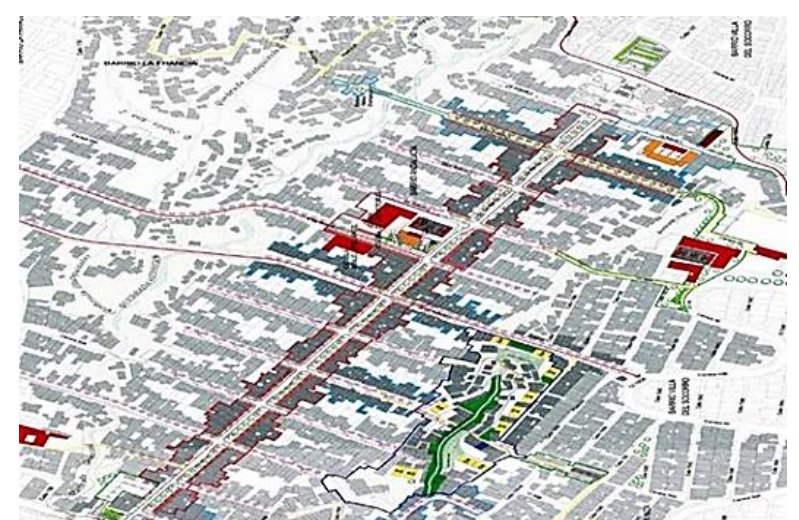

Figure 5: Street making and public transport via cable cars in Medellin (after), (Source: Municipality of Medellin)

\section{5-1-2 Steps followed in upgrading of Madellin}

The opening of space for achieving greater accessibility via metro cable made the provision of good quality streets fig (5), public spaces possible, as well as the provision of schools, public libraries, fig (4). A negotiated process of demolition and relocation provided room for urban regeneration and building the metro cable. Those affected were supported to relocate to new housing within the area or outside by choice (Imparato, Ruster, 2003).

The upgrading of Medellin increased the pedestrian infrastructure from a coverage of $40 \%$ to $60 \%$, brought the infrastructure of streets to $80 \%$ of the area, A high percentage (70\%) agreed that their travel time had decreased, that access to transport had improved (92\%), and that they were better linked to the city $(91 \%)$. The increased presence of the state was recognized by $76 \%$ (Imparato, Ruster, 2003), Political will, civil society involvement and external funding led to the success of the citywide program.

\section{5-2 Citywide slum upgrading project in Agra, India}

This is a summary of the experiment developed by the united nations (UN-HABITAT) in creating a street-led approach to citywide slum upgrading in 16 countries by using streets as tools for urban transformation in slums (UNHABITAT report.2017), Agra is a city with world heritage monuments and historic buildings. It also has 423 slums which house 0.8 million people about $40 \%$ of the city, Agra project aims at implementing slum upgrading on a citywide scale by engaging local stakeholders in a bottom-up planning and implementation process.

\section{5-2-1 Methodology of upgrading in Agra}

The strategy aims to improve slum dwellers life as the opening of streets is the beginning of urban regeneration, and promotes better planning and urban restructuring of slums, improve mobility, accessibility and provision of basic services, as streets are the starting point for a physical integration of slums into the formal systems of planning and urban management (www.citiesalliance.org)

\section{5-2-2 Steps followed in upgrading of Agra}

All city slums have been mapped with spatial boundaries and has digitized these on a city base map using gis geospatial and socio-economic data has been shared with the local communities, it has been used as a base for participatory slum planning (www.citiesalliance.org).

The studies of housing typology, land tenure and tenability status helped to understand land-based challenges of slums.

Slum development models are in-situ upgrading with incremental housing through self-investment, as people are the properties owners, the slum has also redevelopment with land pooling arrangements for areas that are crowded and where plots are small (streets as tools for urban transformation in slums, un-habitat, 2017) fig. (6), (7).

The good geo-spatial and socio-economic data has helped participatory planning and integration of the slum streets and services with the city. Attaching the monuments in The Slum by enhancing the street pattern is a good approach to upgrading in a heritage city.

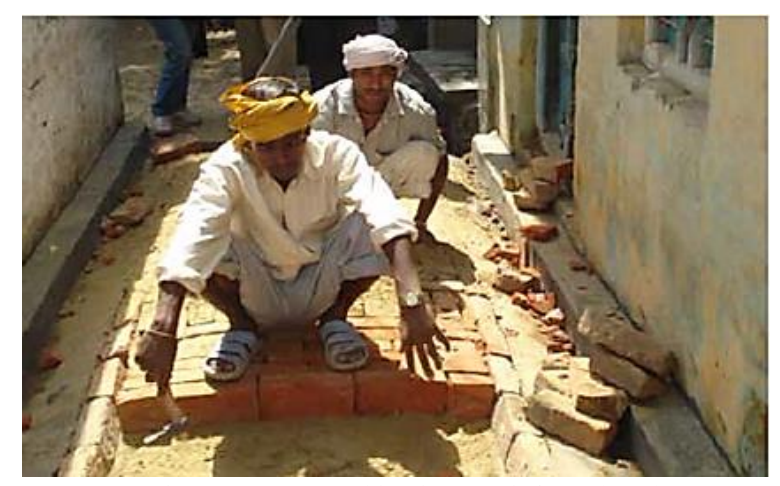

Figure 6: Street making in Agra informal settlements (Source: UN-HABITAT report.2017)

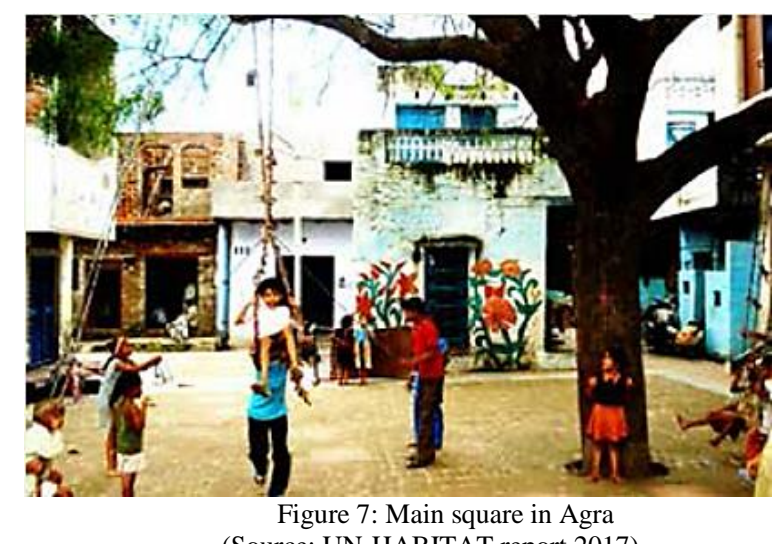

(Source: UN-HABITAT report.2017) 


\section{5-3 The spatial integration of, Badawa slum, Arbil}

This example emphasizes the improvement of a slum through limited physical interventions that affect the internal special structure of it, such as street grids and unused open spaces; which causes the inability to relate to the wider urban context. (Khabat, Saydawa and Bahar, 2015).

\section{5-3-1 Methodology of upgrading of Badawa slum}

The spatial distribution of commercial land use in large slum, relating the internal market locations with the micro scale conditions of spatial structure of informal settlements, mainly the street network morphology, so the commercial activities might effectively locate themselves to maximize their benefit from syntactically more strategic locations.

Socio-economic variations amongst the slums are related to this interplay between commercial land use locations and street network attributes; accommodating internal markets which links its local economy to the wider urban context (Khabat, Saydawa and Bahar, 2015).

\section{5-3-2 Steps followed in upgrading of Badawa slum}

The spatial factors that affect the integration of the slum in the urban fabric of the city are: Developing the edge oriented commercial activity (commercial land use) through outward facing edges, Vacant bordering lands formed from bounding the slum by main streets, a number of vehicular movement routs connect the two sides of the slum to the main streets of the city. The emergence of vacant bordering lands by surrounding the slum with main streets assist using these lands as public land uses (such as education, health ), which help the integration of them (Report on urban settlement upgrading in Iraq, 2013)

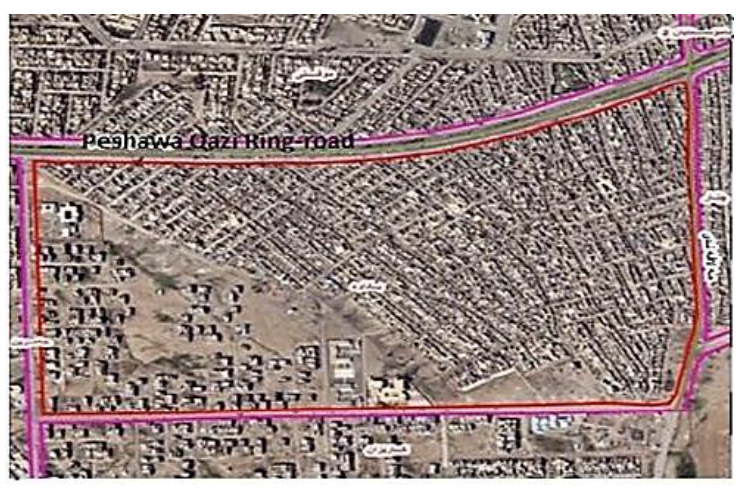

Figure 8: Badawa slum master plane in Erbil city, Iraq (Source: Erbil master plan report.2008)

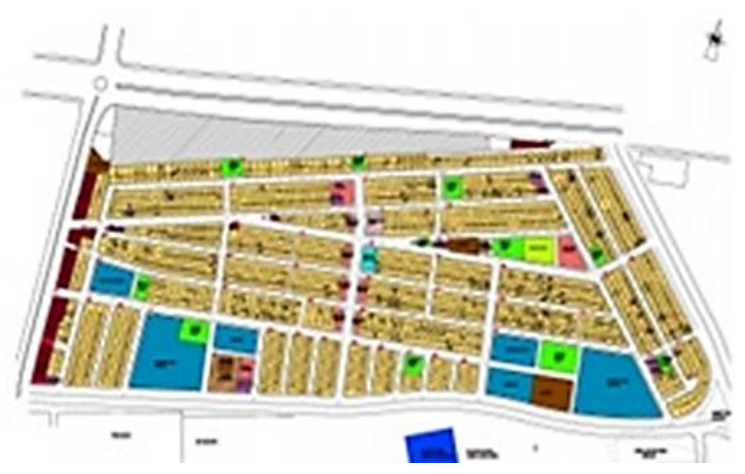

Figure 9: Final master plan and land use map of Badawa Source: Majury, Niall,2013
5-4 Findings of the theoretical and analytical study (Indicators of achieving social sustainable upgrading in slums)

From the previous analysis of the three case studies taking in consideration the practice of changing the use of streets to cope with the population's potentials and needs and they trigger benefits for slum residents.

Through the following analysis in table.(2), we can summarize the axes of achieving socially sustainable development in slums by which the research guidelines in providing a vision of socially sustainable development for the area of Meit Elwan in Kafr El Sheikh city in Egypt, the design principles providing by the research can be a useful checklist for evaluating development proposal for slum's upgrading processes that can help ensuring that sustainability development considerations are included

TABLE 2:

INDICATORS OF ACHIEVING SOCIAL SUSTAINABLE UPGRADING IN SLUMS, (SOURCE: THE RESEARCHER)

\section{Social Sustainability}

\begin{tabular}{|c|c|}
\hline $\begin{array}{l}\text { Social } \\
\text { equity }\end{array}$ & participation and empowerment of women \\
\hline $\begin{array}{l}\text { Human } \\
\text { rights }\end{array}$ & $\begin{array}{l}\text { bring the symbolic attainment of citizenship } \\
\text { rights } \\
\text { integration of slums into the city } \\
\text { administration system }\end{array}$ \\
\hline $\begin{array}{l}\text { Slum } \\
\text { dwellers } \\
\text { participation }\end{array}$ & $\begin{array}{l}\text { participation of a variety of community } \\
\text { groups } \\
\text { participation during all steps of slum } \\
\text { upgrading } \\
\text { participation in decision making over the } \\
\text { street }\end{array}$ \\
\hline $\begin{array}{l}\text { Social } \\
\text { diversity }\end{array}$ & $\begin{array}{l}\text { responsive to gender, youth, children, the } \\
\text { elderly and the disabled } \\
\text { accessibility and social control of public spaces } \\
\text { Optimization of density } \\
\text { promotion of mixed uses }\end{array}$ \\
\hline \multicolumn{2}{|c|}{ Socio-Environmental Sustainability } \\
\hline safty & $\begin{array}{l}\text { identify factors that increase insecurity in the } \\
\text { public space } \\
\text { safety and security of public spaces } \\
\text { social control of public spaces } \\
\text { Streets provide access for emergency } \\
\text { vehicles }\end{array}$ \\
\hline Health & $\begin{array}{l}\text { reduce the effects of natural disasters } \\
\text { green urban design }\end{array}$ \\
\hline $\begin{array}{l}\text { public } \\
\text { awareness }\end{array}$ & \\
\hline \multicolumn{2}{|r|}{ Socio-Economic Sustainability } \\
\hline $\begin{array}{l}\text { local } \\
\text { economic }\end{array}$ & $\begin{array}{l}\text { access to jobs and economic hubs in the city } \\
\text { trigger economic value and local economic } \\
\text { development processes } \\
\text { Improve tenure security }\end{array}$ \\
\hline $\begin{array}{l}\text { training, } \\
\text { development } \\
\text { employment }\end{array}$ & Integrate job creation and vocational training \\
\hline
\end{tabular}




\section{SOCIALLY SUSTAINABLE DEVELOPMENT FOR THE AREA of Mit Alwan in Kafr El SheIKH City}

\section{6- 1 Identifying the study area (Meit Elwan)}

The city of Kafr El-Sheikh is the capital of Kafr El-Sheikh Governorate, which is located in the northern part of Egypt in the Nile Delta. There are some slums in the city but the oldest slum in the city is the area of Meit Alwan, it was called the Damaskilon in Pharaonic designation (en.Wikipedia.org).

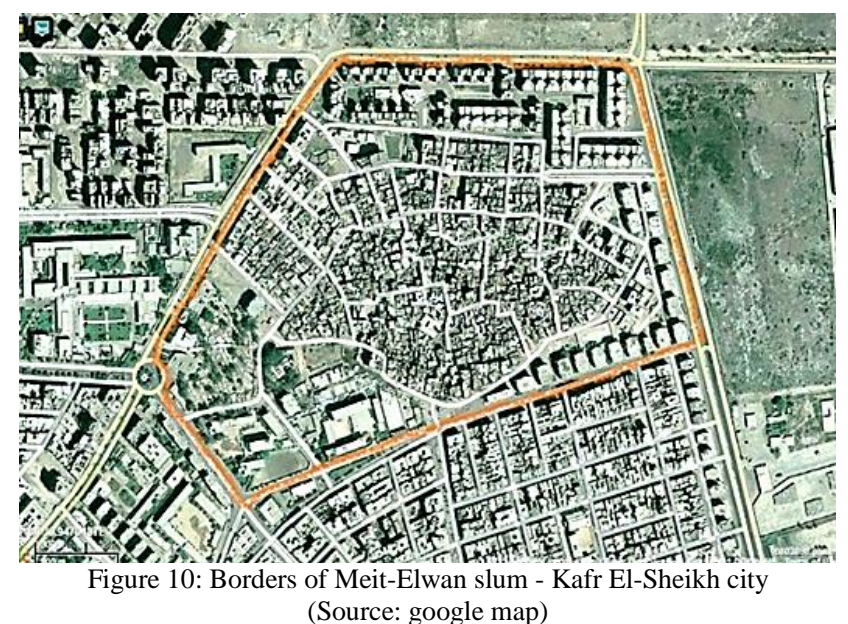

The study area represents a slum within a regulated area as it is surrounded by regular planning from the north and the east and formal governmental schools from the southwest. So, the informal pattern is clearer only in the center which is MeitElwan district. The surrounding physical environment is considered as an envelope containing this area which limits its extension; as those buildings are in good shape and structure unlike the area of Meit-Elwan (fig 11), and the more you head to the center the worth the building structures you get (Kafr El Sheikh Governorate).

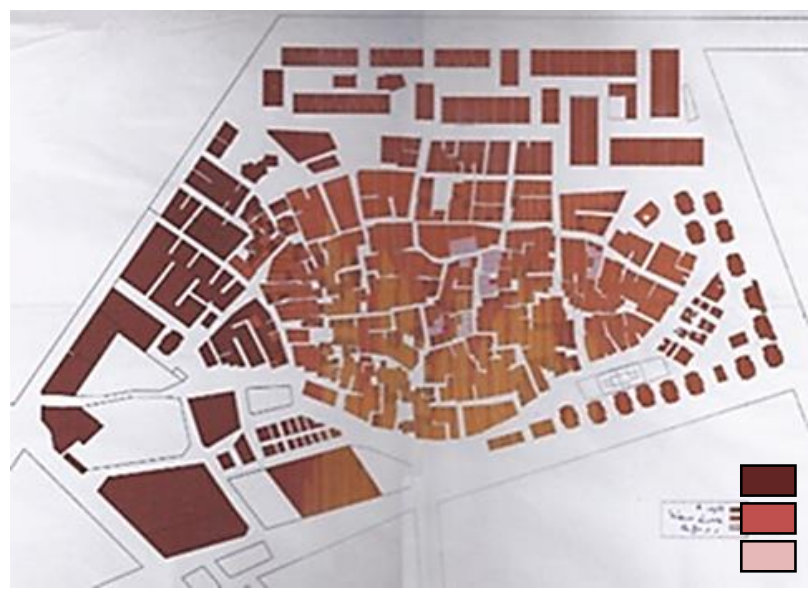

Figure 11: The cases of buildings in Mit-Elwan (Source: (Kafr El Sheikh Governorate).

In the street network, the outside streets are wide, straight, and connected to the second level of secondary streets which are less in width and length, getting to irregular branched streets in the area reaching to its center. These streets are random in distribution, width, and length as well, Fig (12), Fig (13).

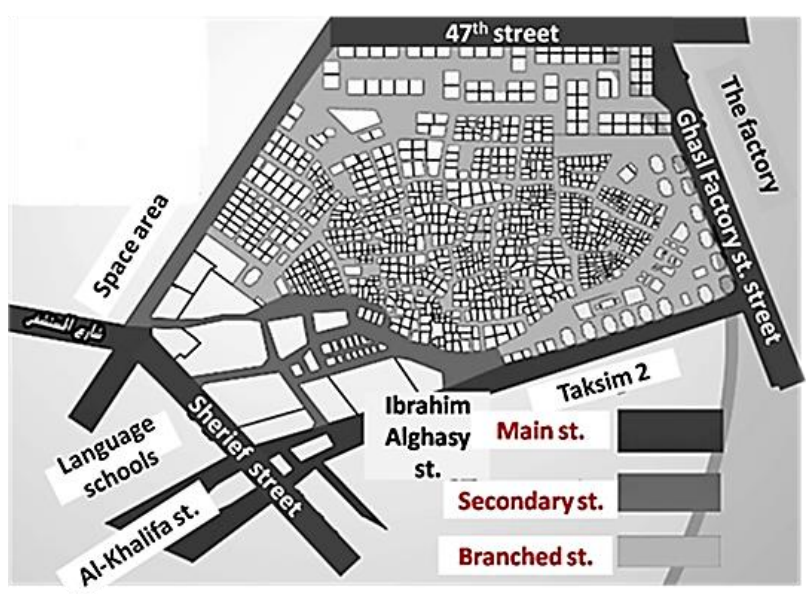

Figure 12: The gradation of streets in Mit-Elwan Source: The researcher

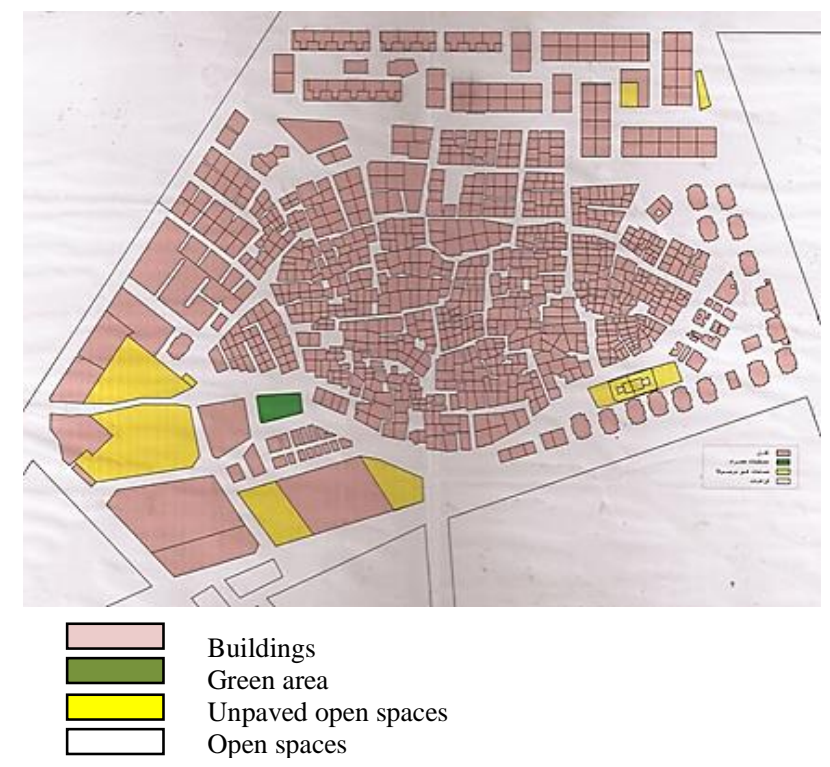

Figure 13:open spaces and buildings in Meit-Elwan slum Source: (Kafr El Sheikh Governorate)

\section{6-2 social sustainable upgrading in Meit-Elwan slum}

The future vision in the research follows street-led city wide slum upgrading approach which was developed by UNHabitat (2012-2017, This approach clears that streets are also tools for social, economic, juridical, and spatial integration of slum with the city. The research vision based on connecting and reconnecting the slum with the city by opening up spaces for infrastructure provision and income generation allow local economic development and enhanced security of land tenure

\section{6-2-1-social sustainability}

\section{6-2-1-1 Social diversity}

a-A slum for all people

c- Optimization of density 
$\checkmark \quad$ letting all segments and age groups of residents partake in social life and providing separate spaces/facilities which are designed for groups of different ages

$\checkmark \quad$-for the elderly: designing comfortable, quiet, and easy to read streets, allow movement without falling or stumbling to elderly with disability

$\checkmark \quad$-for youth: appealing activity spaces such as football facilities, and for children: promoting children's walking, cycling, and outdoor play

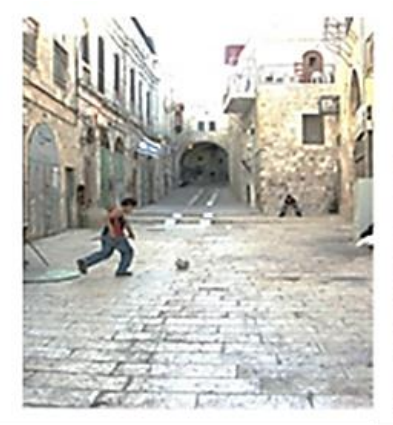

(After)

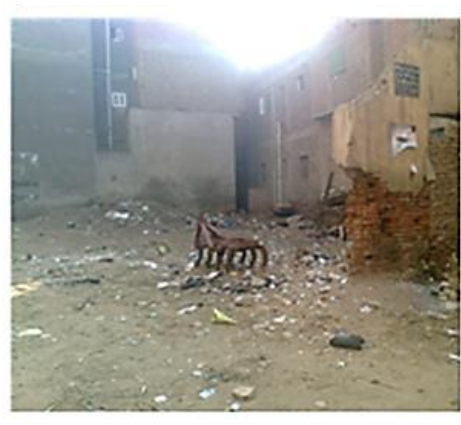

(Before) figure14: upgrading streets to promote outdoor playing source: the researcher

$\checkmark \quad$-Providing paths with suitable surface, wide, and gradients for disabled slum dwellers

$\checkmark \quad$-Including facilities as drinking fountains, toilets, seating, and shade

b- Accessibility and social control of public spaces

- - Designing streets and open spaces to assist in achieving accessibility and social control of public spaces which improve slum's safety.

- - Providing equitable access to all residents

- - Preparing a timely delivery of accessible, wellintegrated flexible community service and social infrastructure.

- - Considering a sufficient size and shape to open space to cater for its intended use.

- - Mixed density is encouraged because it provides housing choice, which promotes a more diverse community and caters for various stages of life, maximizes infrastructure and land.

- - The approach rationalizes slum's structure through an area based plan and street pattern which provides space for streets, open spaces, amenities and infrastructure networks in a way that supports higher densities and mixed use.

d- Promotion of mixed uses

* -Mixed uses can optimize the vitality and perceive security, progress economic development by increasing slum dwellers in streets and open spaces.

* -The implementation of slum street leads to negotiations about relocation of houses, making available for social services and generate mix use slum

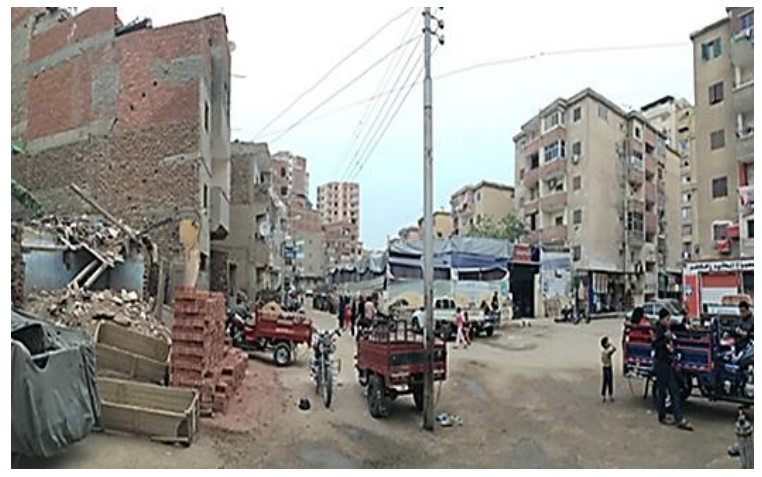

Figure 15: An open space in Meit-Elwan slum Source : The researcher

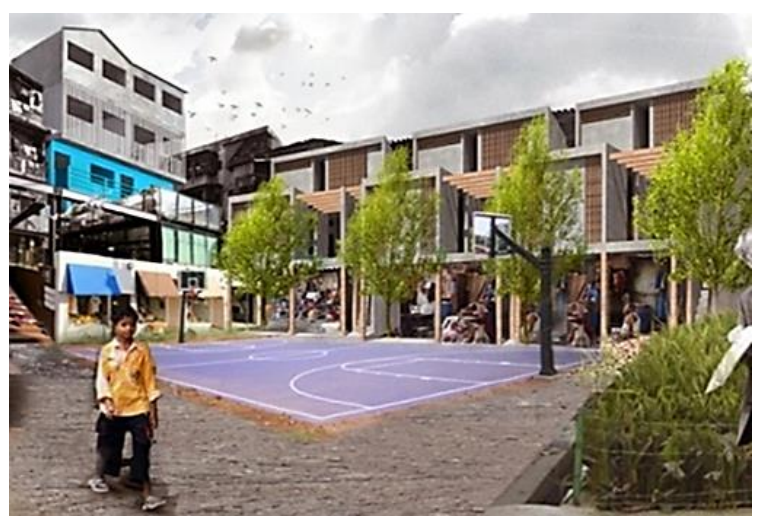

Figure 16: upgrading open spaces to promote social diversity

\section{6-2-1-2 social equity}

Allowing women to participate in all steps of the process and understand their needs

\section{6-2-1-3 Citizenship creation}

Participation of Meit-Elwan slum dwellers will ensure their voice in the process. And their participation in the street naming decision is important to bring local ownership, identity and build self-esteem, As the symbolic attainment of citizenship right will be obtained by the creation of street addresses integration of slums into Kafr El Sheikh city administration system.

\section{6-2-1-4 rights-based upgrading process}

冈 Demolitions and relocation of residents (especially in the degraded areas at the center of Meit Elwan slum) to resettlement sites must be based on participation, prior notification, consultation, alternatives provision, and livelihoods supporting before, during, and after relocation.

$\bigotimes \quad$ The upgrading process must accept the customary rights and legal pluralism when designing the area-based plan of the slum.

囚 The upgrading process must include designing and negotiating relocation plans and including residents and their legitimate grassroots organization in the decision making.

\section{6-2-1-5- slum dwellers participation}

Designing, planning and executing the slum of Meit-Elwan social upgrading program is a participatory and consulted manner by the following steps: 
A. Ensuring participation of all slum community groups including children

B. Ensuring slum's residents participation during all steps of slum development including decision-making and planning participation in decision making over the street

\section{6-2-2-socio-enviromental sustainability}

\section{6-2-2-1 safety}

A. Upgrading places and streets of the slum to reduce crime can foster the mental, physical and social wellbeing of the community

B. The upgrading process Identify and address all factors that contribute the feeling of insecurity through urban design by opening and lighting streets and public spaces in the slum, making sightlines clear and enable chances for surveillance of the streets

C. Enhancing safety of public spaces in the slum by:

- Streets paving, public lighting and mixed use can bring more usage and social interaction between slum residents, so they create more social control of public spaces.

- Greater presence for policing, waste collection can happen by opening slum's streets

- the presence of activity area and corner shops

- associating safety to slum upgrading will allow female residents to go out at evening hours to engage in economic activities and education

\section{6-2-2-2-health}

a) Mental health can be improved by designing facilities to encourage meeting and social interaction

b) Increasing walkability in the slum

囚 -As people who walk, cycle and use public transport have lower obesity, so active transport should be encouraged.

冈 -Insure safety pedestrian paths by having well designed intersections.

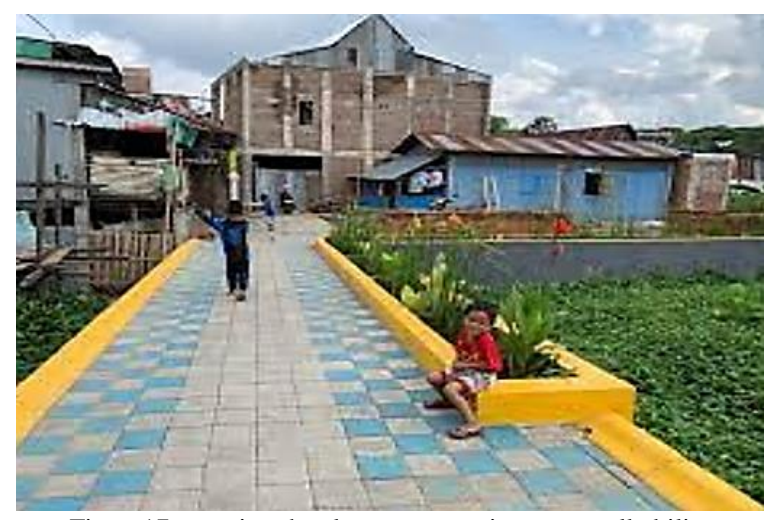

Figure17: opening the slum streets to increase walkability

c) Encouraging active transport

- Providing bicycle storage facilities.
--Developing a sustainable transport framework by integrating public transport into the transport planning process in kafr al sheikh city.

- Providing public transport stops which connect directly with cycling network and pedestrian with providing seating, shelter and lights.

- -Support mixed land uses and densities in the slum.

d) Green urban design reduces the effects of heat drought and wind pattern can be broken by streets

e) Disaster risk reduction

* -opening streets provides emergency vehicles access, space for fire-fighting equipment and residents' evacuation during emergencies.

* reducing natural disasters effects like the flow of heavy rains by the well design surface material and streets pattern

\section{6-2-2-3 public awareness}

\section{6-2-3- socio-economic sustainability}

\section{6-2-3-1 local economic}

- Transferring the local market in Meit Elwan slum to an urban open space on the borders of the slum with the provision of shaded commercial units with the necessary facilities

* opening the slum streets strengthen existing economic activities

* providing mixed land use will enable commerce and shops
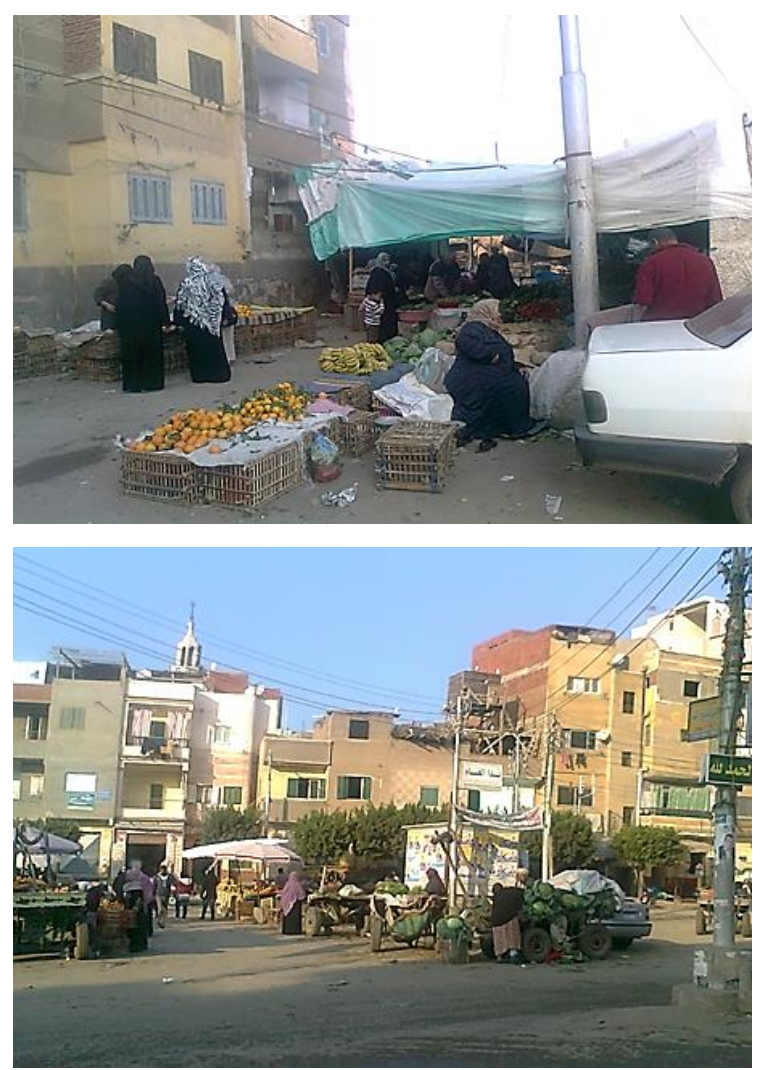

Figure18: Local market in Meit Elwan slum (local economic) Source: the researcher 
6-2-3-2 access to jobs and economic hubs in the city

冈 -Integrating jobs creation and vocational training to support small-scale enterprises during and after the slum's upgrading process.

囚 -Regard long term financing strategies to promote income generation activities and jobs for slum dwellers.

6-2-3-3 sustainability of the slum upgrading program

囚 -Achieving integration and self-financing strategies by establishing cost recovery tools and users' charges

\section{6-2-3-4 Improve tenure security}

囚 -Improving tenure security to enable private investments in home improvement and in activities that generate income by: including formalization and regularization of housing and building

冈 -Creating a base map of registration of property rights by using urban lay out that is registered in public registry.
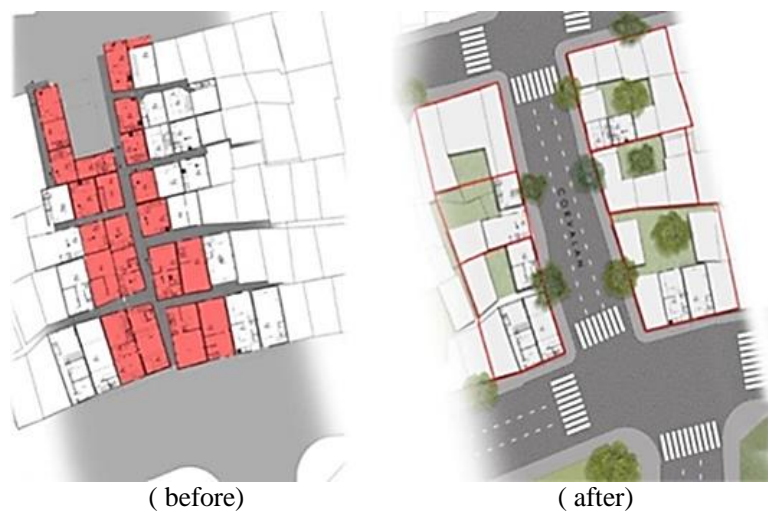

( after)

Figure 19: a plane of a block before and after the opening of streets to achieve connectivity in slum, (source: participedia.net)

\section{6-2-3-5 connectivity}

* -Achieving the connectivity of slum's streets with the shopping and main streets of Kafr Alsheikh city.

* -Designing pattern of streets and public spaces to link the slum with itself and with the city

* -Allowing public transport to enter the slum to increase the recognition of the slum by making it accessible by the city residents.

* -Achieving greater mobility of jobs and people by making a continuous urban fabric.

\section{RESEARCH RESULTS AND RECOMMENDATIONS}

\section{7-1 Research results}

冈 Slums are informal settlements that have inadequate housing, bad living conditions and overcrowded, they also called random housing, poor and illegal neighborhoods, they lack basic municipal services such as water, sanitation, waste collection, and street lighting

冈 Streets are the starting point for the physical integration of slums into the official systems of planning and urban management in the city. Slums streets can have multiple functions, as they are the only public space available in the slum.

冈 Opening public spaces and streets in the slum can achieve greater accessibility and can also strengthen existing economic activities.

冈 Slum upgrading strategies based on social participation provide a great opportunity for the community to become involved in the upgrading process, Slums also include the need for effective urban open spaces to advance human behavior and achieve social interaction.

\section{7-2 Research recommendations}

- Slum upgrading strategies should be comprehensive and include all terms involved in the upgrading process, and the upgrading process for the slums must consider all the indicators to achieve social sustainability as the socioeconomic sustainability and the socio-environmental sustainability.

\section{REFERENCES}

[1] Abdelhalim O., Fadia. Concepts of sustainability as a pillar to support life in urban space,Journal of AL-Azhar University Engineering Sector, 2017.

[2] Ser Al khetem, Tasneem. Population characteristics and their effect on urban design in neighborhood, unpublished master's thesis, Sudan University of Science and Technology Urban design department, 2016.

[3] Betancur, John J, "Approaches to the Regularization of Informal Settlements: The Case of PRIMED in Medellin, Colombia", Global Urban Development Magazine, volume 3 issue 1, 2007.

[4] El Morshedy, Riyam. Urban communities design: Social sustainability as a tool to raise the efficiency of residential neighborhoods, unpublished PHD thesis, Department of Architectural Engineering, Cairo University, 2015.

[5] El Morshedy, Riyam. Ibrahim, Asmaa. Kamel, Rwaida, On the concept of social sustainability within the framework of neighboring residential design, Engineering Scientific Journal, Helwan University, 2015.

[6] El. Eisawy, Mahmoud, Local communities as starting point for achieving global sustainability, Egyptian knowledge bank.www.ekb.eg, January, 2020

[7] El Kattan, Ahmed,Urban Development and Regeneration Methodology in Metropolitan Centers Cairo Down Town as Case Study, unpublished PHD thesis, Architecture Department, Al Azhar University,2009.

[8] Hamid, Mslam K. Analysis of the housing structure of informal housing in Al- Muthanna Governorate

[9] Hassan, Ghada, Evaluating the effectiveness of the role of urban spaces in residential areas, Case study: Residential compounds in Nasr City,Urban planning department,in Shams University,2014.

[10] Ibrahim, Dina, The effectiveness of spatial design between the elements of interior design and the environment. The Fourth International Conference, Faculty of Applied Arts, Helwan University. February, 2016.

[11] Imparato, Ivo, Jeff Ruster. "Slum Upgrading and Participation: Lessons from Latin America, "World Bank.2003

[12] Kafr El Sheikh Governorate.

[13] Ksab, Ahmed S.Elhosiny, Abdelhakim. Mwafak, Hadia. Towards socially effective residential environment in contemporary residential architecture. Tishreen University Journal for Research and Scientific Studies - Engineering Sciences Series Vol. (35) No. (1) 2013

[14] Ksab, Ahmed S.Elhosiny, Abdelhakim. Mwafak, Hadia. Towards socially effective residential environment in contemporary residential architecture. Tishreen University Journal for Research and Scientific Studies - Engineering Sciences Series Vol. (35) No. (1) 2013.

[15] Majury, Niall. Report on urban settlement upgrading in Iraq: Kurani Ainkawa, Erbil, Moving forward, learned lessons. November, 2013. 
[16] Morad, Ahmed M. Sustainable urban development of Greater Cairo as a Metropolitan City. International Journal in: Architecture, Engineering and Technology. BAHETH print. ISSNஜ2536-9946) 2018.

[17] Saad,Ola.Fikry,Mohamed Anwar.Other.Sustainable upgrading for informal areas,Alexandria Engineering Journal,2019.

[18] Taha, Rania. Mutual impact between the urban reality of housing and the social and cultural identity of the population, Case Study: The Old City of Nablus. College Postgraduate studies at An-Najah National University in Nablus, Palestine.2010.

[19] United nations human settlements program report. Streets as tools for urban transformation in slums: street-led approach to citywide slum upgrading,2017

[20] Yousif, Ayman M, Measuring and managing the development of new urban communities through quality of life indicators

[21] Cummins, Robert, Objective and Subjective Quality of Life: An Interactive Model, Social Indicators Research, Vol. 52, No. 1, Oct., 2000

[22] Theofilou, Paraskevi, Quality of Life: Definition and Measurement, Europe's Journal of Psychology,2013

[23] Colantonio Andrea , Social Sustainability: Exploring the Linkages Between Research, Policy and Practice, European Research on Sustainable Development: Volume 1: Transformative Science Approaches for Sustainability,2011

[24] Mensah Justice, Sustainable development: Meaning, history, principles, pillars, and implications for human action, Cogent Social Sciences Journal,2019

[25] Mitchell Lynne and others, Making the outside World DementiaFriendly: Design Issues and Considerations, Environment and Planning B: Planning and Design volume 30, 2003.

[26] http://www.ierek.com/press.
[27] https://www.jstor.org

[28] https://www.iisd.org

[29] https://www.citiesalliance.org

[30] https://unhabitat.org

\section{Arabic Title}

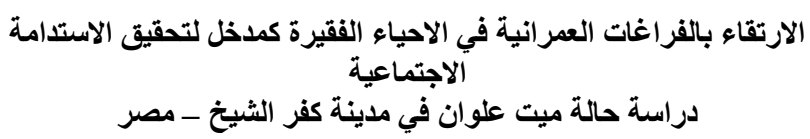

\section{Arabia Abstract}

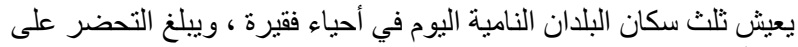

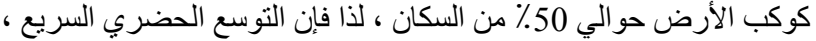

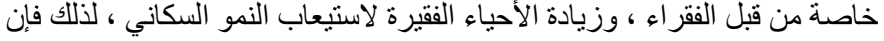

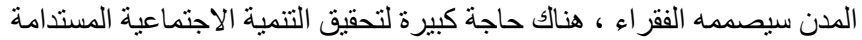

في الأحياء الفقيرة لتوفير الموارد وتحسين نوعية حياة سكان الأحياء الفقيرة.

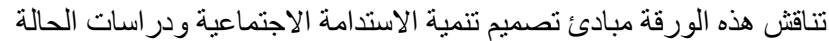

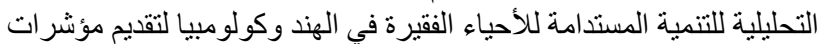
لتحقيق تنمية الاستدامة الاجتماعية للاحياء الفقيرة ، ثم تقدم الورقة در اسة تطبيقية

لتحقيت هذه المؤشر ات في الأحياء الفقيرة في ميت علو ان بمدينة كفر الثيخ في

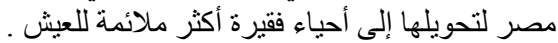

